\title{
Understanding community development in Sekyere Central District, Ghana
}

Kingsford Gyasi Amakye

\author{
*Correspondence: \\ gyasiamakye@yahoo.com \\ Language/Social Science \\ Department, Presbyterian \\ Senior High School, Post \\ Office Box 196, Northern \\ Region, Tamale, Ghana
}

\begin{abstract}
Community development is fundamentally about the development of community involving a sense of common identity, capacity and purpose. It can take the form of unpaid active citizenship with community members organizing themselves and taking on leadership roles. Community development emphasizes empowerment, equality, social justice, participation and representation. This means that community development is fundamentally concerned with decision-making processes affecting users, community-based agencies and services. It is premised on a 'bottom-up' approach, which means enhancing the capacity of communities to determine goals and to pursue issues of importance to them, and to make decisions affecting their lives, for example, the direction of services and the allocation of funds. In Ghana, governments under the various regimes, the community members themselves, and NGOs have promoted the CD practice in several ways since independence in 1957. Preceding governments in Ghana through the Department of Community Development have played a central role in the exercise of CD work. Community development has not been thoroughly investigated in SCDA. This paper gives a clear understanding of CD in SCDA. This paper seeks to assess how the local communities take part in the siting, planning and implementation of development projects in their communities. Further it explores community development projects in the district and how projects are financed in the district. Finally, investigates the obstacles that impede the realization of community development process. This paper was carried out using a mixed method approach. Four area councils in SCDA were randomly selected for this work. These were taken from a total of 10 different local communities spread across the four area council. The study reveals that facilities in terms of education, health, potable water, roads rehabilitation, sanitation and rural electrification have improved tremendously (Fieldwork 2015). The study recommends that policies should be geared towards agriculture to improve the lives of the people in the district since the district is agrarian in nature.
\end{abstract}

Keywords: Community, Development, Understanding

\section{Background}

In Ghana the practice of $\mathrm{CD}$ has received both state and non-state support. While institutions and organizations are contributing to community development over the years, community members themselves are equally contributing with or without any state support for the development of their communities. The collective effort in this endeavour 
implies that the practice of $\mathrm{CD}$ is key for the growth and development of deprived societies (Bonye et al. 2013).

Wharf (1999) notes that in Anglophone Africa, community development during the first half of the twentieth century was informed by the dominant modernization development theory. Provision of infrastructure was perceived as the means of modernizing the so-called primitives of the less developed realm of the world. Hence, the Gold Coast government initiated steps in the early 1940s to promote community development. This effort culminated into the setting up of the community development department by the state in 1948 to focus on rural development (Wharf 1999).

Community development programmes received substantial support from governments and donor agencies. Therefore, many governments promoted development projects that aimed at environmental security, social renewal, and income generation (Cohen 1996). The goals of these projects were to address the poverty, hunger, disease, and apathy that were endemic among the rural and urban poor. Attempts were made to encourage citizens' groups, communities, churches, and NGOs to participate in the projects that could best be handled at the grassroots level. Over the past years, local communities have responded in large numbers to some successful CD programmes that governments and Non-government organisations (NGOs) initiated in the area of health and family planning, education, agriculture, and infrastructure etc. (Cohen 1996). In the 1980s and 1990s, governments in sub-Sahara Africa, including Ghana, increasingly downsized core public service operations, experimented with alternative ways to deliver services, and down-loaded many services from government to communities, civil society organizations and individuals through the decentralization concept (Kokor and Kroés 2001).

There is evidence that community development helps community strengthen itself in order to improve people's lives and addresses issues that have been identified by the community, and builds upon existing skills and strengths within the community. Nevertheless, since community development in Ghana dates back to 1948, after the Second World War when the British colonial regime established the Department of Social Welfare and Community Development, Ghana still struggles to realise the expected developmental progress in most communities (Inkoom 2011).

Regarding participation, findings by ILGS (2014) indicate citizen participation in local governance is generally low as the majority of citizens seem reluctant or perhaps are unable to take advantage of popular participation. Few officials highjack the affairs of most of the communities. This assertion is similar to an earlier finding of the 2008 Afro barometer report (CDD 2008), which suggests that although Ghanaian democratization is advanced in comparison to many other African countries, civic responsibility and civic engagement are low (ILGS 2014).

Again beliefs persist that there is poor sanitation in most of the communities in Sekyere Central district and this has brought about a lot of communicable diseases. No wonder the government of Ghana initiated National Sanitation Day and the district has greatly embraced it and every first Saturday of the month is set aside for communities in the district to embark on clean up exercise and this has improved sanitation tremendously. 
Also in terms of projects initiation, siting, and implementation are questionable given the fact that there are a number of projects either abandoned or not being utilized by the intended beneficiaries even though such projects have been successfully executed. A case in question is a market facility built for the people of Kyebi in Sekyere Central District. This facility which was constructed for the community is lying idle with no one using it while traders sell foodstuffs in some other parts of the community including the streets. This is worrying and brings to question the issue of participation simply because the community members were not actively involved. The question requiring answers is: How are the local population involved in the siting, planning and implementation of development projects in the district? Given these practical challenges, this paper seeks to bring to bear understanding community development in Sekyere Central District.

\section{Theoretical issues}

\section{Literature review}

Community development means different things to different people. For some people, it may be working with a group of individuals on concerns central to them; whereas for others it is a process or a philosophy believing in the capacity of people to solve their own problems. Community development is often associated with terms such as community building, community vitality, community mobilization and community empowerment (Gibbon et al. 2002).

There are many definitions of community development, reflecting its political and indeed contested nature. The starting point for this review is the definition employed by Combat Poverty (2000). According to Combat Poverty (2000), community development is a process whereby those who are marginalized and excluded are enabled to gain selfconfidence, to join with others and to participate in actions to change their situation and tackle the problems that face their community (Combat Poverty 2000). Lee (2003) argues that this definition is rooted in a broad understanding of citizenship that sees people as having a right to influence and participate in the decisions that affect them and to have their experiences and views listened to and acted on. Community development therefore becomes the means or process whereby people can achieve this right. According to Banjoko (2005), Community development is a range of practices dedicated to increasing the strength and effectiveness of community life, improving conditions, especially for people in disadvantaged situations, and enabling people to participate in public decision making and to achieve greater long term control over their circumstances (Banjoko 2005).

From a humanitarian perspective, community development is seen as a search for community, mutual aid, social support, and human liberation in an alienating, oppressive, competitive, and individualistic society. In its more pragmatic institutional sense, it may be viewed as a means for mobilizing communities to join state or institutional initiatives that are aimed at alleviating poverty, solving social problems, strengthening families, fostering democracy, and achieving modernization and socio-economic development (Campfens 1997). According to Mendes (2008), community development is the "employment of community structures to address social needs and empower groups of people". It is a prime mover of people because it gets people to actively participate in issues that affect them. Community development is fundamentally about the development of community involving a sense of common identity, capacity and purpose. It can 
take the form of unpaid active citizenship with community members organizing themselves and taking on leadership roles. Community development emphasizes empowerment, equality, social justice, participation and representation. This means that community development is fundamentally concerned with decision-making processes affecting users, community-based agencies and services. It is premised on a 'bottom-up' approach, which means enhancing the capacity of communities to determine goals and to pursue issues of importance to them, and to make decisions affecting their lives, for example, the direction of services and the allocation of funds (Centre for Effective Services 2009).

Conceptualizing community development in the twenty-first century, Matarrita-Cascante and Brennan (2012) indicated that "Community development is a process that entails organisation, facilitation, and action, which allows people to establish ways to create the community they want to live in. It is a process that provides vision, planning, direction, and coordinated action towards desired goals associated with the promotion of efforts aimed at improving the conditions in which local resources operate. As a result, community developers harness local economic, human, and physical resources to secure daily requirements and respond to changing needs and conditions". Vancouver Coastal Health (2013) also states that "Community development is the process of helping a community strengthen itself in order to improve people's lives. It addresses issues that have been identified by the community, and builds upon existing skills and strengths within the community". From the forgone discussion of community development, this paper adopts Vancouver Coastal Health (2013) definition as a working definition.

\section{Principles and processes that underpinned community development}

The key to community development is facilitating a community in applying the principles to guide a flexible series of actions that are appropriate for the situation of the community. There are many models and frameworks for community development processes. There is a trade-off between communities having clear future plans for steps in the process and retaining flexibility and versatility. Considerable skill, confidence and judgment are needed to maintain an adaptable community-led process guided by the principles of community development (Shaffer 1989). It requires an indepth knowledge of the culture, livelihoods and range of perceptions in communities, including the past history of development in the area that may have caused disempowerment and dependency. To achieve the above principles for community development, it is essential to:

- Give priority to the needs and interests that the community identifies as their starting point, and involve them to the maximum extent possible in the design, implementation, monitoring and evaluation of interventions.

- Recognize that the community is not a homogenous group but is made up of many subgroups, and therefore that efforts need to be made to ensure all community members are able to influence the decisions that affect their lives. It is important to ensure that efforts do not adversely affect the disadvantaged members of a community.

- Encourage self-determination, self-help and self-reliance among beneficiaries by supporting rather than leading them. Build their capacity rather than just provide inputs. 
- Seek to enhance gender equality in terms of the rights and responsibilities of men and women, as well as the various age groups in the community respecting and valuing diversity and difference.

- Ensure that there is sufficient attention paid to addressing the underlying constraints to development, whilst raising the community's awareness of the range of choices open to it (REGLAP 2012).

Community development takes place in a range of settings. For example, inner urban cities, suburbs of cities, small towns, villages, rural areas. Community development again takes place in different types of communities. For example, geographical communities such as housing estates, communities of interest, new communities. It also takes place in different policy contexts. For example national, regional or local contexts such as antipoverty, regeneration, anti-drugs, area based partnerships (Peter et al. 2000). According to Mayer (2004), Brophy and Shabecoff (2001), community development has three goals: to change the economy of the neighborhood, to improve the physical nature of the neighborhood, and to strengthen social bonds between people in the neighborhood. The essence of community development is well captured in the Budapest declaration, which focuses on strengthening civil society, empowerment and an agenda of social change. Community development is a way of strengthening civil society by prioritizing the actions of communities, and their perspectives in the development of social, economic and environmental policy. It seeks the empowerment of local communities, thus both geographical communities, communities of interest or identity and communities organising around specific themes or policy initiatives. It plays a crucial role in supporting active democratic life by promoting the autonomous voice of disadvantaged and vulnerable communities (Mayer 2004; Brophy and Shabecoff 2001)

According to Kenyon (1994), there is no set of instructions for a community development process. Rather, there are many models and frameworks for community development processes. There is a trade-off between communities having clear future plans for steps in the process and retaining flexibility and versatility. The following are general steps that describe the sequence of key steps in a community development process. These steps are not prescriptive, but they rather describe the usual stages that most communities go through during a versatile process of community development. These steps are: community preparedness, "bubbling" concern, stimulus, initial organisation and involvement and engagement and issues identification. Communities need to have some of the key ingredients for a development process thus motivation, local leadership, a sense of ownership. Not all communities are interested in, or prepared for, undertaking a process of community development at any one time, only a few communities may see the need, or have people motivated to organize and lead the community in development activities (Kenyon 1994).

Community development processes develop from a situation where issues and concerns are "bubbling" around. People are concerned, enthusiastic, motivated, frustrated. Private troubles become public concerns as people share issues that matter to them individually. People may begin to see some advantage for them in community improvement. They also may have altruistic feelings of contributing to the welfare of the whole community. Often, a stimulus brings the "bubbling" situation to a head. A local crisis, such as 
business leaving town sparks community action. A local leader, a local community group or several concerned citizens may galvanise community action. After a stimulus, often the first step is an event that brings the community together usually at a public meeting or forum. At this point, community representatives may invite a facilitator or resource person into the community to help with suggestions, information and the process itself. Some community members may have a clear idea of what is needed or what they want to do. Others may simply want to do something to improve their community but are not sure of what to do (Shaffer 1989). After initial organisation, a key step is activities to engage local people and give as diverse range of citizens the opportunity to be involved. Engagement of people occurs throughout a community development process, but it is crucial to actively foster involvement early in the process. There are several important aspects of engagement. First, it involves understanding the existing concerns of community members. Second, it is important to ask citizens how they would like to participate. In many community efforts local leaders overlook this. They often choose participation opportunities that they are familiar with, often opting for traditional meetings and committees by default. There are many techniques for engagement and issues identification. They include one on one discussion, surveys, focus groups, public meetings, and many more. Community development is a process that leads to not only more jobs, income and infrastructure, but also communities that are better able to manage change. Community members can better mobilise existing skills, reframe problems, work cooperatively and use community assets in new ways. Principles of self-help and participation guide a flexible process. While there is no recipe, major steps are identifying existing concerns, engagement, self-examination, exploration, prioritization, planning and action (Kenyon 1994).

\section{Challenges and benefits of community development Challenges}

According to Lee (2003) , the reliance on public funding underpins the realization of community development. It would appear that the community development sector has come to rely on public money. This is also potentially problematic. There is an inherent conflict in a situation where the State provides resources to organisations whose stated aim is to change the State, even though such provision is also an important statement of the State's willingness to be criticized and to hear the voice of those who experience poverty and exclusion. Considerable skills and resources are required to use this contradictory position to good effect. There have been some examples of funding lines coming under threat because of differences between funders and activists in relation to the way resources have been used. This has included a reluctance to fund research work, although quality text-based research is a key tool in the development and articulation of a social change proposal. It has also included a reluctance to fund actions aimed at informing and influencing wider public opinion (Lee 2003). Another challenge facing community development is its focuses on short term. Programme support for community development is generally provided on a short-term basis in cycles of 3 , or fewer, years. This timeframe leads to strategies that are demonstrably achievable within such a timeframe and a potential reluctance to commit resources over time to difficult and complex issues. There is, however, no short-term solution to poverty issues. The 
constraints of short timeframes may also impact on evaluation mechanisms. There is evidence that quantitative indicators are given greater weight than qualitative indicators, not least because the latter may be more difficult to document and measure. For example, an evaluation mechanism that measures the number of young people in contact with a project does not differentiate between a project that engages with a small group of participants to provide them with intensive supports on a daily basis and one that meets large numbers of young people once a week (Combat Poverty Agency 2000).

Again, community development is facing staffing problems. Effective community development is labour intensive. The task of building the self-confidence and the capacity of communities to make alliances and achieve positive outcomes is a time-consuming and resource consuming process. It requires skilled workers, on the ground, involved on a daily basis with individuals and groups. It is notable, however, that the community development sector, like many public services working with those who are living in poverty, is creating more opportunities for managers in response to programme demands and for specialists such as policy workers. The sector is failing, or is unable, to adequately invest in and retain skilled workers directly charged with building voice and capacity (Lee 2003).

\section{Benefits}

The importance of community development cannot be over emphasized. Community development builds and maintains social capital. Social capital can be defined as the norms and networks that enable people to act collectively (Woolcock and Narayan 2000). There are a number of tools that can be used to build and maintain social capital. One, creating accessible and activated hubs of activity for social interaction. Two, fostering the formation of viable community groups and sporting organisations. Three, organizing events and activities that bring people together. At a local government level, social capital improves community confidence, heightens community participation rates, enhances wellbeing, reduces crime and improves economic prosperity. In Western Australia, which has a significant land-based economy, this is particularly important, as families are looking for places that have a strong sense of community. Investors are also looking for places which are safe, stable, innovative and likely to attract skilled labour and inspirational consumers (Knack 2002). Fukuyama (1995) adds that social capital lowers the transaction costs of doing business, and that in such environments people are more likely to be innovative, creative and take risks (Fukuyama 1995).

According to Shragge (1993), community development has seen major growth in the development of our cultural community. In recent years, we have witnessed a proliferation of artists gaining international recognition and of poets, authors, and musicians. The increase in the number of local theater productions, festivals as well as recent growth in the film industry has generated an awareness of who we are as a people. This growth and recognition is advantageous for several reasons. Firstly, cultural activities attract people to our towns both on a short-term and long-term basis. Secondly, identity may form the basis of an outward marketing strategy, making it easier to sell homegrown products. Thirdly, in acknowledging our unique collective identity, we become prouder of whom we are and invest in ourselves, our future, and our own products, generating even more local employment (Shragge 1993). 


\section{The theory of self-reliance}

Self-reliance is one of the bases of effective community development in most of SubSaharan Africa. In fact, the theory of self reliance is located centrally within the discourse of community development and is connected to related concepts like self-help, mutualhelp, indigenous participation and rural development. It advocates the need for people to improve their condition using local initiatives and resources in their own hands. The concept is fast being accepted as a new formula for community development. Its widespread acceptance in the development planning of most African countries has the tendency to give greater stimulus and cohesiveness to community development in these countries (Anyanwu 1992). Anyanwu (1992) contends that in most African countries, community development has depended significantly on voluntary cooperative efforts. This follows a traditional trait that clearly underscores the virtue of self-reliance. This explains the emerging trend in community development, which sees it as an important point of take-off for better living. The emphasis is to involve groups of people in planned programmes from which they may gain skills that will enable them to cope more successfully with the problems of their everyday life. Self-reliance is thus "development on the basis of a country's (region's) own resources, involving its populations based on the potentials of its cultural values and traditions" (Anyanwu 1992). Communities and individual people define their own development according to their own needs, values and aspirations (Anyanwu 1992).

Hence, Local-level development no doubt provides a major force in activating the utilization of local resources (land, water, labor) and therefore constitutes one of the most effective methods of promoting people's participation in determining their own development. This accounts for the wide acceptance by many scholars of the needs for local alternatives and self-reliance in repositioning the rural system. For instance, Brett (1988) has called for cooperative and voluntary alternatives, while Sandbrook (1985) has emphasized the need for "small-scale community solutions". Several literatures on community participation and development have unanimously agreed that in most subSaharan African villages including Nigeria, communities have contributed to developing their infrastructure and social services. Self-reliance is a key factor in community development which demands that community members apply their knowledge and skills to the resources at their disposal. This is in perfect accord with Anyanwu's observations that the development of related skills and attitudes of a people can enable them to satisfy their basic needs, to grow self-reliant, and to minimize precarious dependence on agencies external to their communities (Sandbrook 1985). Sandbrook (1985) aptly noted that the concept of self reliance is closely allied to the principles of self-help and mutual help. The Oxford Advanced Learner's Dictionary defines self-help as "the use of one's own efforts, resources, etc. to achieve things, without depending on others". In other words, it is "do-it-yourself" (DIY). Self-help initiatives enable the people to look inwards by rallying local resources and efforts. This is especially appropriate to the concept of community development, which stresses the importance of people increasing their sense of responsibility, and looking for assistance as just supplementary, but never replacing popular initiatives or local efforts. The emphasis is on democratising with reliance on what people can do for themselves. The principle of self-help incorporates into the community development process the means of offering ordinary citizens the opportunity 
to share in making important decisions about their living conditions (Anyanwu 1992). In the Sekyere Central District under study, most of the communities have contributed to developing its infrastructure and social services through levying of members in the communities and through communal labour. For example in Nsuta which is the district capital, members in the town through the effort of the chief and other opinion leaders have constructed police station which has gone a long way to check armed robbery in the town and its environs. Self-reliance in community development demands that community members apply their knowledge and skills to the resources at their disposal. This ties in with Anyanwu's observations that the development of related skills and attitudes of a people can enable them to satisfy their basic needs, to grow self-reliant, and to minimise precarious dependence on agencies external to their communities. In Cameroon, the water management committees that are an auxiliary of the Village Development Associations are very instrumental in handling problems that relate to distribution and maintenance of water points. In the case of Lower Mbot (Donga-Mantung Division) women were levied $500 \mathrm{frs}$ and men $1000 \mathrm{frs}$ for the maintenance of its water system. In Mbinkar (a nearby locality), the Village Development Association is very supportive in road rehabilitation through cleaning of culverts, chopping of grass around major roads and the filling of potholes. Membership contributions constitute an important source of start-off capital for execution of projects (Jua 2002).

\section{Research methodology}

In all, four area councils, namely Nsuta, Beposo, Kwaman and Kyebi were covered by the study. Nsuta was purposively selected because it is the district capital and the fact that it constitutes not only a sizeable proportion of the total number of the population in the district but also it has diverse ethnic groups across the district. The simple random sampling, the lottery method, was used to select three area councils out of the seven (7) in Sekyere Central District. In this method, pieces of paper were cut using the same measurement and the names of the area council were written on them. Each piece of paper was folded, rolled and put in a container. The pieces of paper were then thoroughly mixed. The rolled papers were then picked one by one without the selector looking into the container. This process went on until the targeted three communities were selected.

Participants for the household interviews were randomly selected. However, the categories turned out to represent a rather diverse core of local community actors. The study initially targeted 20 participants from each area council. However, including responses from the instrument pre-test yielded a total of 76 responses. That is $21,20,18$ and 17 responses respectively from area councils A, B, C and D. These were taken from a total of 10 different local communities spread across the four area council. Though randomly selected, the study gained more responses from male respondents than female as indicated in Table 1.

\section{Data collection}

Data collection is the process of obtaining data for a research (Driscoll et al. 2007). Data for this mixed-method research were obtained from questionnaires, interviews, observation, documents sampling, field notes (Creswell 2009). Questionnaires were administered physically. In-depth face to face interviews using structured and semi structured 
Table 1 Area council male female total. Source: Fieldwork 2015

\begin{tabular}{llcc}
\hline Area council & Male & Female & Total \\
\hline A & 18 & 3 & 21 \\
B & 15 & 5 & 20 \\
C & 13 & 5 & 18 \\
D & 10 & 7 & 17 \\
Total & 56 & 20 & 76 \\
\hline
\end{tabular}

questionnaires were undertaken for the collection of both qualitative and quantitative data. Document sampling involved the search and review of documents about the subject under investigation (Yin 1994). This paper thus employed a concurrent embedded mixed methods strategy for data collection. This involves using a single phase for collecting both quantitative and qualitative data simultaneously (Creswell 2006).

\section{Data analysis}

The data analysis in this study was guided by the fact that the research is both qualitative and quantitative in nature. Qualitative and quantitative data were collected and analyzed simultaneously. Data processing involves editing the questionnaires; coding and entering them initially into excel before importing the data into Statistical Programme for Social Scientists (SPSS) for analysis. The questionnaires were coded, then data entered into the SPSS programme, and were analysed. The researcher used the analysed data to interpret and compile the results in the form of tables and figures. To ensure that data collected are of maximum quality, the questionnaires were edited to check for consistency of the response and in an event that information collected were not of desired quality, I went back to the respondent (s) for confirmation.

\section{Community development in Ghana: background}

Community development in Ghana dates back to 1948, after the Second World War when the British colonial regime established the Department of Social Welfare and Community Development. The growth of CD during the 1950s was one of the most important factors in the social and economic development of the country. The efforts of politicians, civil servants, and churches-all struggling to define an effective CD program for the country-traditional local leaders contributed through their often superior knowledge and skills in the area of village development (Kokor and Kroés 2001).

Community development (CD) gained considerable impetus in the colonial era for a number of reasons. The first reason relates to the success of the farmers' co-operatives that had been established between 1929 and 1931 (Brown 1984). Most of the cocoa farmers who belonged to co-operatives relied on traditional techniques of self-help and mutual aids (called nnoboa) to prepare the cocoa beans for fermentation and drying. Also, basic services and infrastructures in rural areas (such as clinics, schools, feeder roads, and water) were poor. Their poor condition necessitated a CD strategy that relied on indigenous resources. Adult literacy was promoted through $\mathrm{CD}$ campaigns. The programme captured the enthusiasm of the 'educated few' in the villages-including teachers, clerks, and store-keepers and persuaded them to act as volunteer teachers (Bonye et al. 2013). 
Nkrumah gave CD top priority after the Convention People's Party won the general election and assumed power in 1952. In adopting the guidelines of Universal Education Program that had been developed by the colonial administration 6 years before independence, a detailed plan was formulated and tabled in the legislative assembly in 1952 and approved unanimously. The plan stressed literacy education and self-help among the population and signaled the government's readiness to collaborate with those who sought to help combat illiteracy in the country (Bonye et al. 2013).

However, after independence, the Community Development Department found itself caught in a political crossfire as government and ideologies began to change rapidly. As a result, most of the functions and structures of community development dramatically changed over time, though the approach remained the same. Nkrumah turned the community development operation into an arm of the new Ministry of Labour and Social Welfare, with the goal of establishing co-operatives that would conform to the government's socialist policies. Despite all these, community development programs such as self-help projects, adult education, and women's work and extension campaigns continued to be promoted. Communities must be involved at all stages of projects if they are to succeed in promoting community development (Kokor and Kroés 2001). It has been empirically proven that programmes with citizens participation coordinated by community level officials have generally been more successful than those without it (Ahwoi 2010). It is important to state that the ousting of Nkrumah's administration by the National Liberation Council (NLC) and the subsequent transfer of political power to Busia's progress party (PP) in 1969, did not significantly change the community development agenda and programmes (Brown 1984).

During the early months of the National Redemption Council (NRC) administration, which ousted the Busia government in 1972, CD programs became more popular; the regime heavily promoted self-reliance and established programs such as Operation Feed Your Self and Operation Feed the Industries. In the urban areas, people began to plant cassava, plantain and vegetables in their backyards, while in the rural areas people increased their production. However, because of administrative mismanagement, the self-help ideology did not last long. The Third Republic, under President Limann, did not make any major changes to community development (Kendie 2006).

When the Provisional National Defense Council Party (PNDC) under Rawlings came to power in 1981, the Community Development Department was separated from Social Welfare and placed under the Ministry of Local Government (Jefferies 1992). The goal of the separation was to bring together departments that promoted local development so that the local people and their communities could have more input into decision-making and benefit directly. The prevailing conditions of poverty, disease, and apathy have led, in recent years, to the development of associations, groups, and NGOs. Among these associations, are women's groups, producers' and traders' associations, environmental organisations, and church groups, which aim to empower the poor and develop intermediate organisations. It is interesting to note that among the domestic NGOs, the Ghana Rural Reconstruction Movement has been very active in promoting adult education and self-help village projects; it also provides extension services to farmers (Gorman 2010). In various localities in Ghana, there is an emerging proliferation of informal networks and organisations, which are involved in various aspects of community development initiatives (Kendie 2006). 


\section{The case study: community development in Sekyere Central District}

The Sekyere Central District with Nsuta as its capital is geographically located within longitude $0.05^{\circ}$ and $1.30^{\circ} \mathrm{W}$ and latitudes $6.55^{\circ}$ and $7.30^{\circ} \mathrm{N}$ in the Ashanti Region of Ghana. It was created by the former President, Kufuor which was inaugurated on the 29th of February 2008. It was formally part of Sekyere West District. Sekyere Central District Assembly is under the Ministry of Local Government and Rural Development (MLGRD) of the Republic of Ghana. It covers a total land area of about 1564 sq.km. Has about 105 settlements with about 70\% being rural. SCDA area of jurisdiction includes Nsuta, Kwaman, Beposo, and its environs and shares a common boundary with Sekyere South, Mampong, Ejira- Sekyere Dumasi, Afigya Sekyere, and Afram Plains all in Ashanti and Amantin in the Brong Ahafo. The vision of the district is to ensure accelerated development and its mission is to raise the living standards of the people in the district through formulation and implementation of policies in support of agriculture, health, education and social infrastructure. The district is generally low lying and gradually rising through rolling hills stretching southward towards Nsuta. The highest point is $2400 \mathrm{~m}$ whilst the lowest is $135 \mathrm{~m}$ above mean sea level. It is fairly drained by several streams and rivers like Afram, Sene, Sasebonso, and Kyirimfa. The district has about three (3) paramountcies which include Nsuta, Kwaman and Beposo. The district has twenty-nine (29) electoral areas with seven (7) towns or Area councils. Large settlements in the district include Nsuta, Kwaman, Beposo, Kyebi, Atonsu and Jeduako. Vegetation type in the district is secondary forest and Savanna Transitions. The mean annual rainfall is between 800 and $1500 \mathrm{~mm}$. Moreover $80 \%$ of the land area is used for small scale farming. From the analytical report from Ghana Statistical Service puts the total population of Sekyere Central District at 71,232 (Ghana Statistical Service 2014). The district map of Sekyere Central map is shown in Fig. 1.

\section{The role decentralized local government plays in community development in Ghana}

Decentralisation as a political process to enhance democracy and development has been a key development strategy in Ghana since 1988. The Ghana government (under the various regimes), the community members themselves, and NGOs have promoted the CD practice in several ways since independence in 1957. Preceding governments in Ghana through the Department of Community Development have played a central role in the exercise of CD work. In the past three decades or more, government has been the sole initiator of community development work. For instance, in the early months of the NRC administration, CD activities were very prominent. It promoted self-reliance through the Operation Feed Your Self programme under the leadership of Kuntu Acheampong where individual farmers and farmers' associations increased their production levels. Since the PNDC era, decentralisation concept has been central in the promotion of community development in which local leadership takes active part in the local development projects, such as: schools, clinics, water points, KVIP construction, and road construction and maintenance among others (Bonye et al. 2013). Nonetheless, for the past two decades, governments in Ghana have used the decentralisation model to promote CD through the institutional framework of the Metropolitan, Municipal and District Assemblies (MMDAs). It is important to stress that NGOs, Faith-Based Organisations (FBOs), 


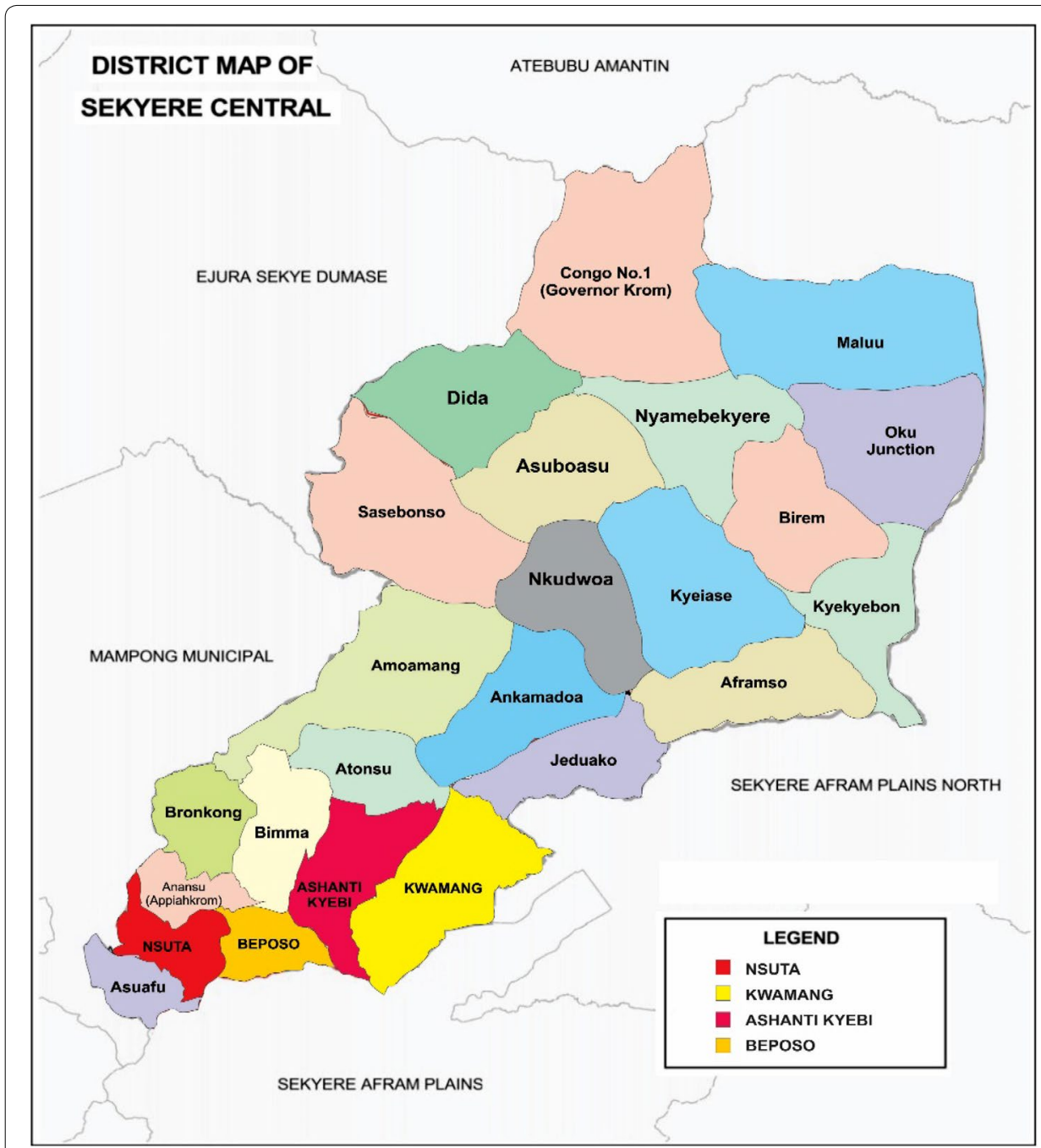

Fig. 1 District Map of Sekyere Central District

Community Based Organisations (CBOs) and private individuals are increasingly complementing the role of government in community development in recent times (Cohen 1996).

However, one project that has made a tremendous contribution towards community development is the Community-Based Rural Development Project (CBRDP), which was implemented from October 2004 to June 2011 under the Ministry of Local Government and Rural Development. Through this Project, health facilities and schools have sprung up in many rural communities, while hundreds of rural folk have found successful jobs after acquiring employable skills and credit through the Project. There are many pointers to the success of the Project, but one that is most central is the direct involvement of the local people in the planning and execution of the Project. Needless to say that many interventions in the past had not succeeded simply because invariably, the people for whom the interventions were targeted were not given the space to contribute. With this approach, the CBRDP has proven to be a real project for Ghana's rural communities (Adusei-Asante 2012). 
The Government of Ghana initiated the CBRDP in 2004 as part of its poverty reduction strategy aimed at using full community participation to reduce rural poverty and build capacity to strengthen the local government system. The project aimed at contributing to the overall empowerment of rural folk to enable them participates actively in issues that affect their daily lives. By strengthening the capacity of rural communities, the project has succeeded in enhancing the quality of life of the people through the improvement of infrastructure and access to key support services from public and private sources. The project collaborated with a number of ministries, departments and agencies notably the Ministry of Education, Ghana Education Service, ARB Apex Bank, Community Water Sanitation Agency, National Development Planning Commission, and Ghana Health Services among others. Direct project implementation was handled by district assemblies and area councils, with regional coordinating councils harmonizing, coordinating and monitoring project implementation (Adusei-Asante 2012).

In the last quarter of 2014, the Ministry of Local Government instituted the programme called National Sanitation Day which takes place first Saturday of every month in all the ten regions in Ghana. This day is observed to clean our cities, towns and communities in Ghana. The exercise has greatly helped to improve sanitation in Ghana and has also reduced diseases such as Cholera and malaria in the country.

\section{The results and finding}

\section{Community involvement}

When asked whether the community involvement has any relevance for project planning and implementation process, $83 \%$ of respondents said Yes community involvement has relevance on project planning and implementation. Only $17 \%$ of respondents said No. The literature confirms that the involvement of the people entails allowing them to discover the possibilities of exercising choice and thereby becoming capable of managing their own development. Consequently, participatory development embodies a process of enlarging peoples' choices (Martinussen 1997). Adusei-Asante (2012) again reported that by strengthening the capacity of rural communities, the CBRDP in 2004 has succeeded in enhancing the quality of life of the people through the improvement of infrastructure and access to key support services from public and private sources. Through this Project, health facilities and schools have sprung up in many rural communities. The CBRDP has proven to be a real project for Ghana's rural communities (Adusei-Asante 2012). The theory of participatory development confirms this finding by saying that participation is not confined primarily to the involvement of local communities in development projects, but concerns the development of organizations in which local people can articulate their interests and defend what they treasure (UNDP 1993).

\section{Community members' involvement in planning, implementation and siting of projects}

Communities must be involved at all stages of projects if they are to succeed in promoting community development (Kokor and Kroés 2001). It has been empirically proven that programmes with citizen's participation coordinated by community level officials have generally been more successful than those without it (Ahwoi 2010). The finding reveals that about more than half of the community level officials were actively involved in the planning, implementation, and siting of projects in Sekyere Central District. Again, 
Amponsah and Boafo-Arthur (2003) pointed out that the major objectives for establishing the district assemblies were the recognition that they would serve the crucial purpose of promoting popular participation in planning, implementation of development policies and programs in the district. This gives a lucid picture that majority of the community level officials were actively involved in projects in their communities as seen in Fig. 2.

Again, the perception of the involvement of community members in projects is not completely misplaced. It is consistent with the findings. With massive involvement of communities in projects in SCD has promoted community development projects. The findings suggest that $89.5 \%$ of sampled respondents said Yes because their involvement has helped to promote developmental projects in the district. Only $10.5 \%$ of respondents said No.

\section{Government project in your community for the last 5 years}

When asked whether the community members know of any government project in their communities for the last 5 years, all the respondents representing 100\% said Yes. Again all the respondents confirmed that the projects have been beneficial in diverse ways.

\section{Kinds of project}

A critical look at the kinds of projects undertaken by the district as seen in Fig. 3 reveals that, $43 \%$ of respondents said educational projects, $27 \%$ of respondents said health

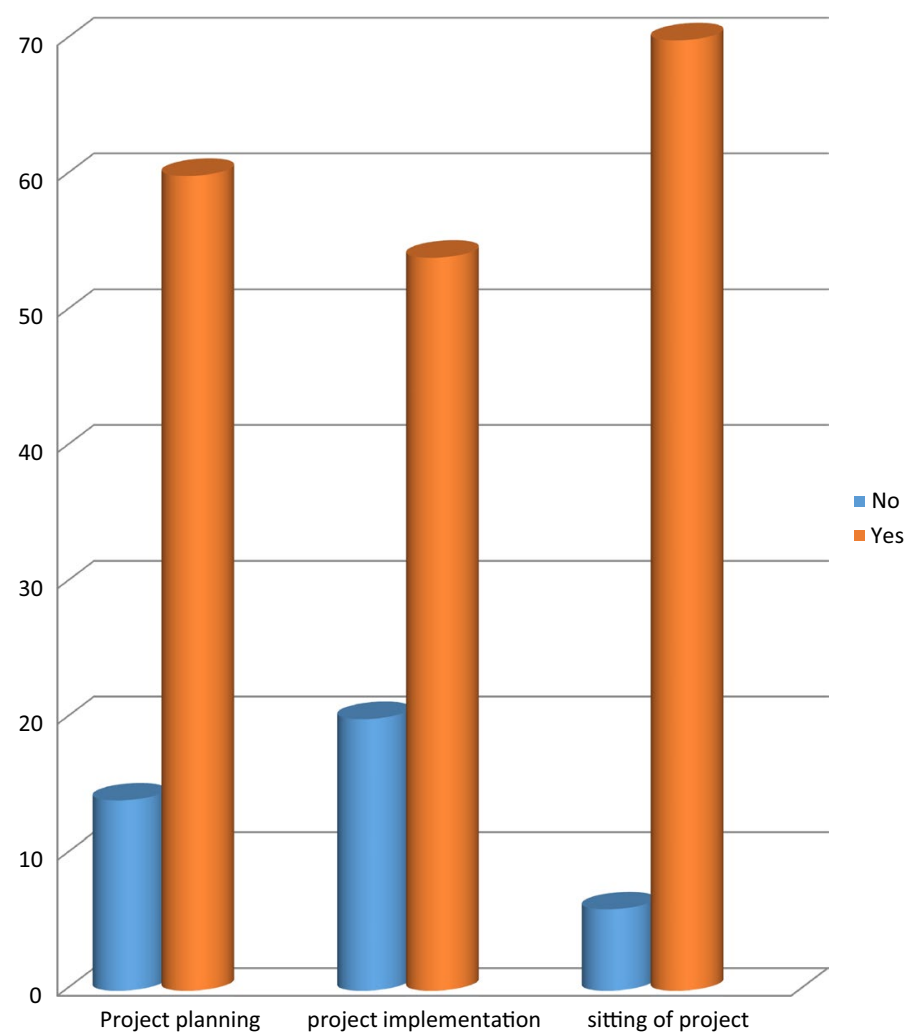

Fig. 2 Community members' involvement in planning, implementation and siting of projects (Source: Fieldwork 2015) 


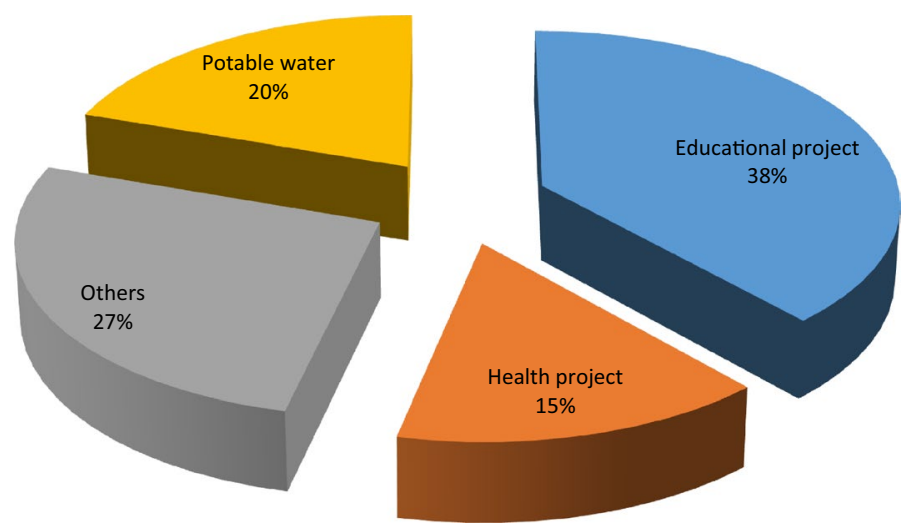

Fig. 3 Government projects in Sekyere Central District (Source: Fieldwork 2015)

projects. Again $18 \%$ of respondents said portable water projects and $12 \%$ of respondents said other projects such as building of police station and construction of feeder roads. From the data you could deduce that the health sector has fallen short in Sekyere Central District. This assertion confirms Nsibambi (1998) that, in health, provision of medical care and services has fallen far short of local needs through lack of finances. A survey of health services conducted in 1996 in Uganda found that the most common problem facing the health sector was that no drugs were being provided to patients. This was because most of the grants transferred to districts for health had been used for salaries.

\section{Projects financed by the district}

Findings from Fig. 4 reveal how projects are financed in the district. With this, 79\% of sampled respondents said the district projects were financed by the central government. Also $16 \%$ of sampled respondents said projects in the district were financed by the assembly's internally generated funds. Only $5 \%$ of sampled respondents said the projects were financed by Non Governmental Organizations. This data shows that majority of

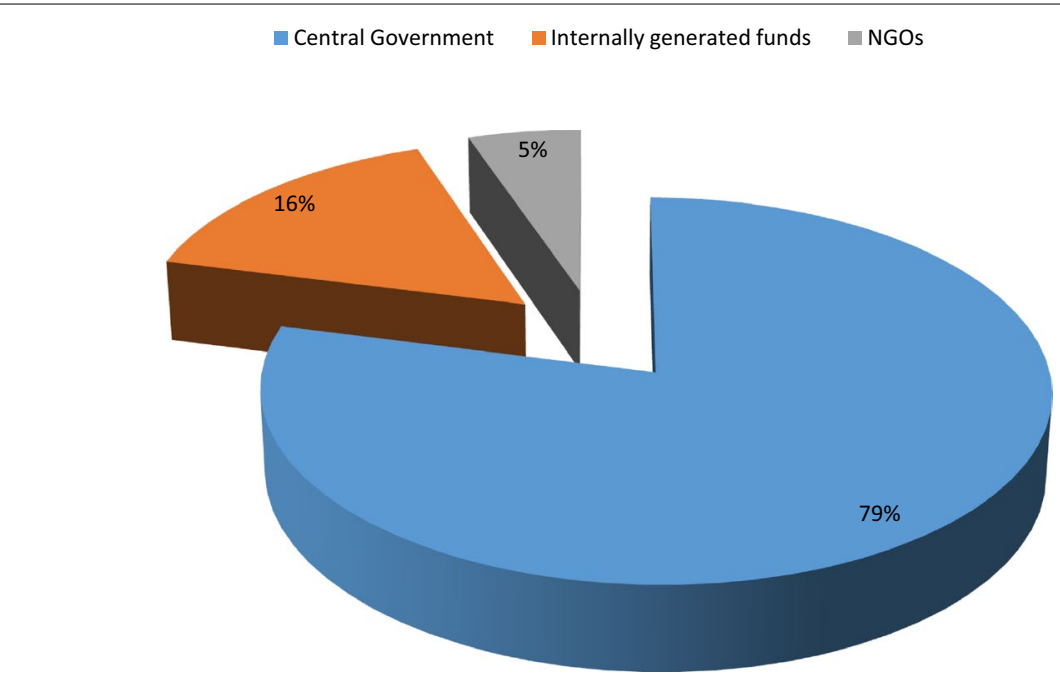

Fig. 4 Projects financed by the district (Source: Fieldwork 2015) 
the projects were financed by the central government. Again, the literature argues that the district should adopt the theory of self reliance to reduce the over dependence of the central government funds which at times are not forthcoming.

\section{Opinions on the level of sanitation}

When the respondents were asked to grade the level of sanitation in the district, $47 \%$ of respondents said the level of sanitation was very good. Also $38 \%$ of respondents said the level of sanitation was good. Again, $12 \%$ of respondents said sanitation in the district was pretty good. Only $8 \%$ of respondents said sanitation was bad in the district. This gives a greater impression that there is tremendous improvement in sanitation in the district. This finding is in line with the Ministry of Local Government programme called National Sanitation Day which takes place first Saturday of every month in all the ten regions in Ghana and this has gone down to the grassroots. This day is observed to clean the cities, towns and communities in Ghana. The exercise has greatly helped to improve sanitation in Sekyere Central District and Ghana as a whole and has also reduced diseases such as Cholera and malaria in the Sekyere Central District. This is illustrated in Fig. 5.

\section{Improvement in the level of infrastructure}

When participants were asked whether the level of infrastructure has improved in Sekyere Central District, in fact all the respondents representing 100\% said Yes. This indicates that the level of insfrasture has improved. Bonye et al. (2013) confirm that since the PNDC era, decentralisation concept has been central in the promotion of community development in which local leadership takes active part in the local development projects, such as: schools, clinics, potable water, KVIP construction, and road construction and maintenance among others (Bonye et al. 2013). The community members also made mention that educational, health, potable water, roads rehabilitation, sanitation and rural electrification have improved tremendously (Fieldwork 2015).

\section{Problems of community development in SCD}

In the analysis of problems facing development of communities in SCD, $81 \%$ of respondents said lack of funds to support community development work impedes the realization of development in the district. Also 13\% of respondents said lack of logistics support

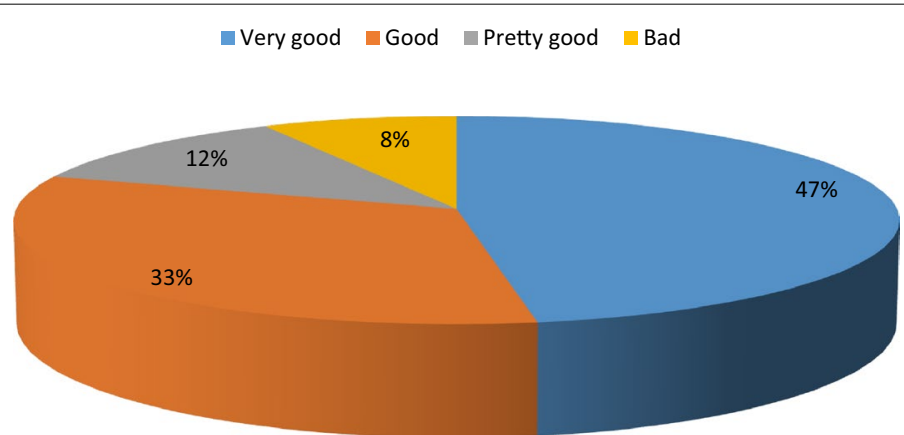

Fig. 5 Opinions on the level of sanitation in the district (Source: Fieldwork, 2015) 
affect development in the district particularly those living in the hinterlands to discharge their duties. Only $6 \%$ of respondents said politicization of development process in the district slows down development. This picture indicates that funding is the main obstacle to development in SCD as indicated in Fig. 6.

\section{Sustaining $C D$ in $S C D$}

The finding presents the sustainability of community development in SCD. In the analysis, 36\% of sampled respondents said CD in SCD can be sustained through sensitization of both assembly members and the entire citizenry to know their duties and act accordingly. Again, 24\% of respondents said policy in SCD should be geared towards agriculture to boost the local economy since the district economy is an agrarian one. Also, $22 \%$ of respondents said District Assembly Common Fund should be released on time to undertake developmental projects and finally $18 \%$ said proper monitoring should be enforced. A tracking study of the DACF in four districts in 2003 by a group of Civil Society Organizations' in Ghana confirms that there were delays and shortages in disbursements, misuse of DACF (Azeem et al. 2010) as seen in Fig. 7.
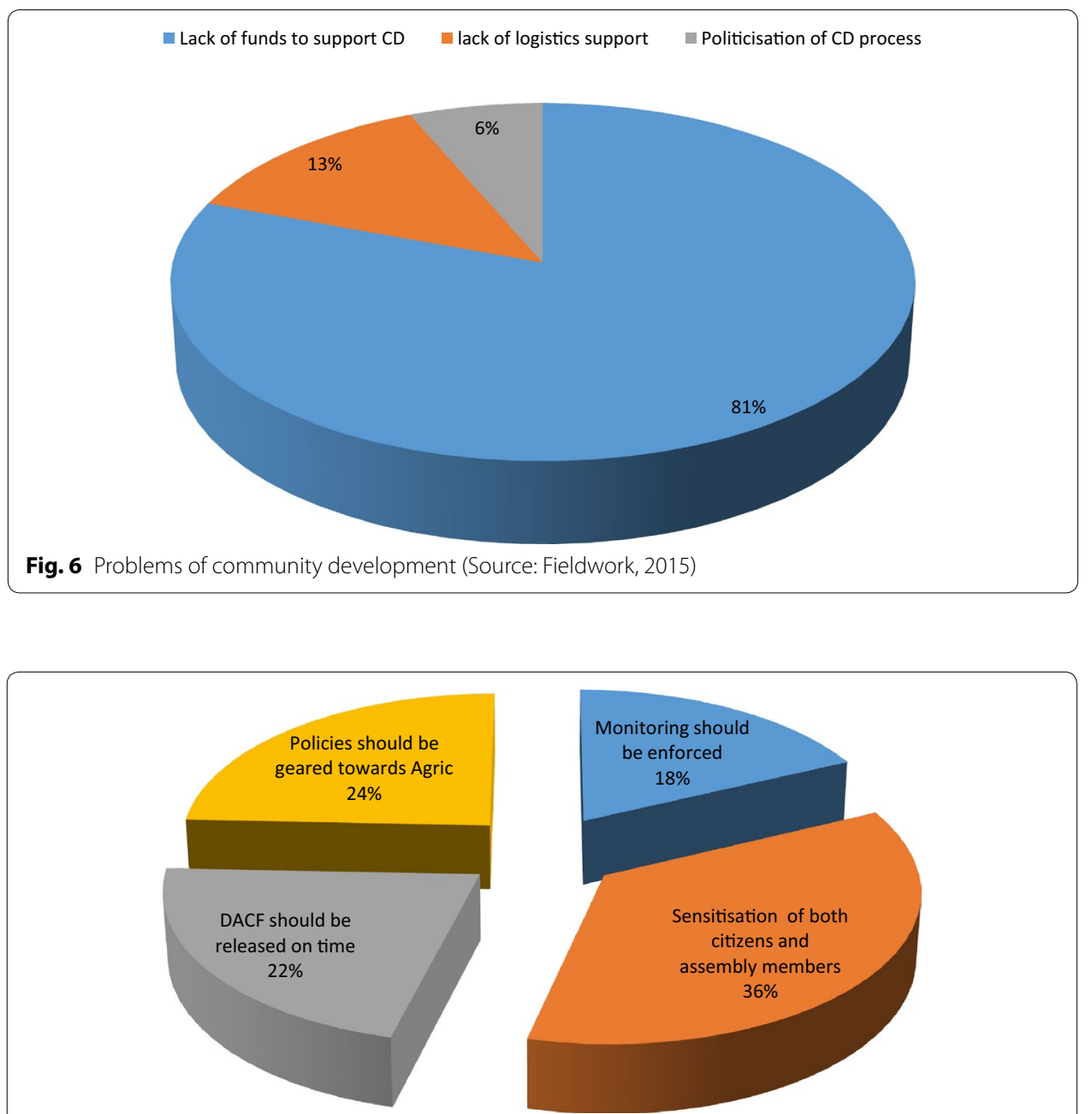

Fig. 7 Opinions on sustaining community development in SCD (Source: Field Work 2015) 


\section{Addressing community development in SCD}

When respondents were asked to suggest ways to address the challenges of community development in SCD as seen in Fig. 8, sampled respondents representing 55\% said the assembly should devise ways to encourage internally generated fund. Again, $27 \%$ of respondents said there is the need to educate members that development of their community is their major responsibility. Also $18 \%$ of sampled respondents said DACF should be released on time to support community development work.

\section{Conclusion}

In general the results provided give clear understanding of community development in Sekyere Central District. Community development is a process that leads to not only more jobs, income and infrastructure, but also communities that are better able to manage change. Principles of self-help and participation guide a flexible process of CD. Again the main challenges facing communities in terms of development in SCDA are lack of funds, lack of efficient committed leaders and poor attitude towards community work. Also, SCD is doing well in community development in terms of rural electrification, improvement in health and educational infrastructure and improvement in feeder roads. The Ghana government (under the various regimes), the community members themselves, and NGOs have promoted the CD practice in several ways since independence in 1957. Preceding governments in Ghana through the Department of Community Development have played a central role in the exercise of CD work. It is important to stress that NGOs, Faith-Based Organisations (FBOs), Community Based Organisations (CBOs) and private individuals are increasingly complementing the role of government in community development in recent times (Cohen 1996).

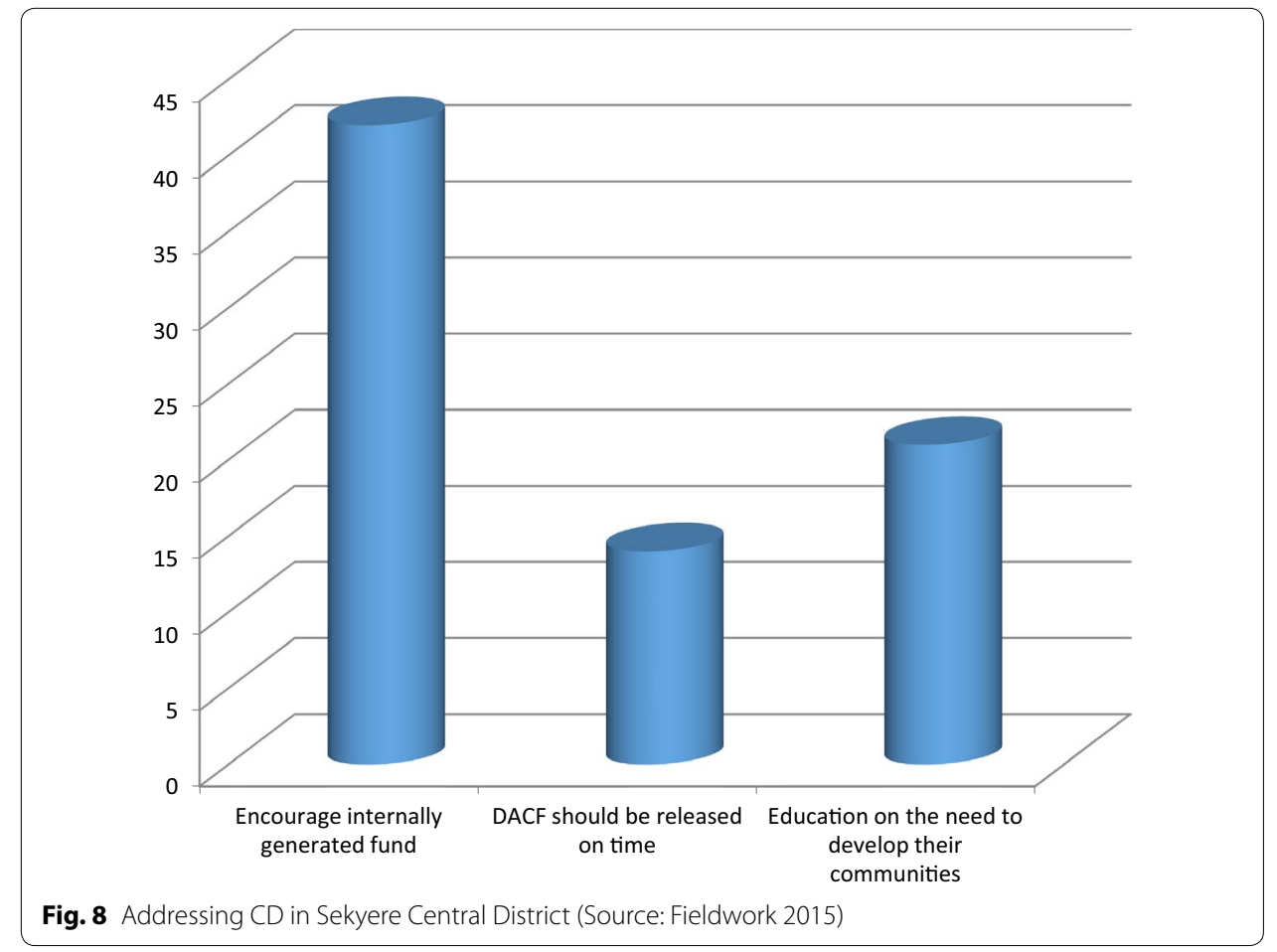


In the last quarter of 2014, the Ministry of Local Government instituted the programme called "National Sanitation Day" which takes place first Saturday of every month in all the ten regions in Ghana. This day is observed to clean our cities, towns and communities in Ghana. The exercise has greatly helped to improve sanitation in Ghana and has also reduced diseases such as Cholera and Malaria in SCDA.

\section{Acknowledgements}

My first thanks go to the almighty God for making this work a successful one. My first thanks go to Dr. Mohammed Sulemana who supervised my Mphil thesis through which this work is produced. Again express my gratitude to Mr. Tweneboah Koduah for painstakingly reading through this manuscript for me. I cannot forget my wife Margaret Konadu who helped in data collection and entry and Mr. Raymond adabor for his contribution to the map. This work is self financed.

\section{Competing interests}

The author declares that he has no competing interests.

\section{Publisher's Note}

Springer Nature remains neutral with regard to jurisdictional claims in published maps and institutional affiliations.

Received: 30 September 2016 Accepted: 4 August 2017

Published online: 15 August 2017

\section{References}

Adusei-Asante, K. (2012). The state of Ghana's local government system: the case of AssemblyMembers. Inkanyiso: Journal of Humanities and Social Sciences, 4(2):101-110.

Ahwoi, K. 2010. Local government and decentralisation in Ghana. Accra: Unimax McMillan.

Amponsah, N., and Boafo - Arthur, K. (2003). Ghana's Democratic Renaissance: An Overview. In: Local Government in Ghana: grassroots participation in 2002 Local Government Elections. Accra: Uniflow Publishing Ltd, p.4.

Anyanwu, C. 1992. Community development: the Nigerian perspective. Ibadan: Gabesther Educational Publishers.

Azeem, V.A., C. Abbey, and K.B. Kuupiel. 2010. Tracking the Ghana district assemblies common fund. In Demanding good governance: lessons from social accountability initiatives in Africa, ed. M. McNeil, and C. Malena, 71-88. Washington, DC: World Bank

Banjoko, T. (2005). New Trends in Community Development, Tools for Community Development. Unicore International Conflict research

Bonye, S.Z., A.T. Aasoglenang, and E. Owusu-Sekyere. 2013. Community development in Ghana: theory and practice. European Scientific Journal 9 (17): 79-101.

Bret, E. 1988. Adjustment and the State: Problem of Administrative Reform. IDS Bulletin 19(4):4

Brophy, P. and Shabecoff, A. 2001. A Guide to Career in Community Development, London: Island press

Brown, C.K. 1984. Government and voluntary participation in Ghana's rural development programmes. Accra: Ghana University Press.

Campfens, H. 1997. Community development around the world: practice, theory, research, training. Toronto: University of Toronto Press.

Centre for Effective Services. 2009. Effective community development programmes. An executive summary from a review of the international evidence. Dublin: $\mathrm{NCl}$.

Cohen, S. 1996. Mobilizing communities for participation and empowerment. In Participation for social change, ed. J. Servos, T.L. Jacobson, and S.A. White. New Delhi: Sage.

Combat Poverty Agency. 2000. The role of community development in tackling poverty. Dublin: Combat Poverty Agency.

Creswell, J. W. (2006). Qualitative inquiry and research design, 2nd ed. London: Sage Publication, Inc.

Creswell, J. W. (2009). Research Design: Qualitative, Quantitative and Mixed Methods Approaches, 3rd ed. Thousand Oaks, California: Sage Publications.

Driscoll, D. L., Appiah-Yeboah, A., Salib, P., and Rupert, D. J. (2007). Merging qualitative and quantitative data in mixed methods research: how to and why not. Ecological and Environmental Anthropology 3(1):19-28.

Fieldwork, (2015). Decentralisation and community Development in Sekyere Central District, Ghana

Fukuyama, F. 1995. Trust: the social virtues and the creation of prosperity. New York: Free Press.

Ghana Statistical Service. 2014. Population and Housing Census, National Analytical Report. Gibbon, M., Labonte, R., and Laverack, G. 2002. Evaluating community capacity. Health and social care in the community. 10(6): 485-491.

Gibbon M., Labonte R., and Laverack G. (2002). Evaluating Community Capacity. Health and Social Care in the Community 10(6):485-491

Gorman, E. (2010). Community Economic Development Movements in Rural Ghana: Using Agricultural Technologies to Alleviate Poverty, Shepherd Poverty Progam Papers

Inkoom, D.K.B. 2011. Ghana's decentralization: two decades and still crawling? Development 54 (3): 393-399.

Institute of Local Government System (ILGS). 2014. State of local democracy report. Accra, Ghana.

Jefferies, R. (1992). Urban attitudes towards the economic recovery programme and government in Ghana. African Affairs 92:207-26. 
Jua, N. 2002. Small is not always beautiful: a case study of the njinikom area development association. Nordic Journal of African Studies 11 (3): 336-358.

Kendie, S.B., and Guri, B. 2006. Indigenous institutions, governance and development: community mobilisation and natural resources management in Ghana. In: International Conference on Endogenous Development and Bio-Cultural Diversity, 332-349. Geneva, Switzerland.

Kenyon, P. (1994). Ready Set Go: Action Manual for Community Economic Development. Melbourne: Municipal Association of Victoria.

Knack, S. 2002. Social capital and the quality of government: evidence from the States. American Journal of Political Science 46 (4): 772-785.

Kokor, J.Y., and G. Kroés. 2001. Central Grants for Local Development in a Decentralized Planning System, Ghana. Spring Research Series 23. Dortmund: University of Dortmund.

Lee, A. 2003. Community development in Ireland. Community Development Journal 38 (1): 48-58.

Martinussen, I. 1997. Society, state and market. A guide to competing theories of development. London: Zed Books.

Matarrita-Cascante, D., and M.A. Brennan. 2012. Conceptualizing community development in the twenty-first century'. Community Development 43 (3): 293-305.

Mayer, N.S. (2004). Education and training for community development. Building the Organizations That Build Communities, p.249.

Mendes, P. (2008). Teaching community development to social work students: A critical reflection. Community Development Journal 44.2:248-262.

Nsibambi, A. (1998). Decentralisation and Civil Society in Uganda: The Quest for Good Governance. Kampala: Fountain.

Peter, T., A. Barr, and S. Hashagen. 2000. Achieving better community development. London: Community Development Foundation

REGLAP. 2012. Good practice principles on community development for use in the drylands of the horn of Africa. November 2012. Research, Training. Toronto: University of Toronto Press.

Sandbrook, R. 1985. The politics of Africa's economic stagnation. Cambridge: Cambridge University Press.

Shaffer, R.E. 1989. Community economics: economic structure and change in smaller communities. Ames: lowa State University Press.

Shragge, E. (1993). The Politics of Community Economic Development. Community Economic Development. In: Search of Empowerment. Montreal: Black Rose Books, 1-17.

UNDP. 1993. Human development report, 1995. New York: Oxford University Press.

Vancouver Coastal Health. (2013). Community Development Get Involved. Available at: http://www.vch.ca/get_involved/ community-development/. Accessed 8 Feb 2013.

Wharf, B. 1999. Community development in Canada. Community Development Journal 34(4):267-269.10.1093/ $\mathrm{cdj} / 34.4 .267$.

Woolcock, M., and Narayan, D. (2000). Social Capital: Implications for Development, Theory, Research, and Policy. The World Bank Research Observer 15:225-49.

Yin, R. K. (1994). Case Study Research: Design and Methods, Applied Social Research Methods Series, 3rd ed. London: SAGE Publications.

\section{Submit your manuscript to a SpringerOpen ${ }^{\circ}$ journal and benefit from:}

- Convenient online submission

- Rigorous peer review

- Open access: articles freely available online

- High visibility within the field

Retaining the copyright to your article

Submit your next manuscript at $\boldsymbol{\text { springeropen.com }}$ 